\title{
Strategic Ways of Minimizing Banks’ Bad Loan Debts
}

\author{
Nelia Volkova, \\ Department of Finance and Banking \\ Vasyl Stus Donetsk National University \\ Vinnytsia, Ukraine \\ nelia.volkova.donetsk@gmail.com \\ http://orcid.org/0000-0003-3790-3636 \\ Alina Glushko, \\ Department of Finance and Banking \\ Poltava National Technical Yuri \\ Kondratyuk University \\ Poltava, Ukraine \\ glushk.alina@gmail.com \\ http://orcid.org/0000-0002-4086-1513
}

\author{
Valeriia Volkova, \\ Department of Finance and Banking \\ Vasyl Stus Donetsk National University \\ Vinnytsia, Ukraine \\ valeriya.volkova.donetsk@gmail.com \\ http://orcid.org/0000-0003-1539-6194
}

\author{
Liana Ptashchenko, \\ Department of Finance and Banking \\ Poltava National Technical Yuri \\ Kondratyuk University \\ Poltava, Ukraine \\ lianaptaschenko63@meta.ua \\ http://orcid.org/0000-0002-4228-0421
}

\begin{abstract}
The strategic directions for minimization banks' bad loan debts were studied. The essence of the problem loan as a type of bank assets was found out and the authors' interpretation of this definition was suggested. Substantiated was the authors' adjusted approach to the classification of problem loans, which refines specifics and scope of their emergence. The volume of problem loans within Ukraine's banking system in general and at JSC Oshchadbank in particular was analyzed. It is suggested that banks can improve the way they manage bad loan debts in the post-crisis Ukraine by developing a strategy for minimizing bad loan debts and introducing the LVPC coverage ratio for potential bank claims at JSC Oshchadbank instead of the LTV coverage ratio used in most banks.
\end{abstract}

Keywords - problem loan, adversely classified assets, loans in the early warning stage, loans with identified signs of problem, overdue loans, discount rate.

\section{INTRODUCTION}

The financial and economic crisis has significantly aggravated Ukraine's banking system. This has become especially noticeable in those areas of bank activity that have been developing rapidly so far, that is, on the administration of loans because non-repayment of loans has a significant impact on the functioning of the banking system of Ukraine. Therefore, improving the way banks administer bad loan debts is of particular relevance. A thorough analysis of the current trends in the development of Ukraine's banking system shows that lending is decreasing, however, the share of problem debt in loan portfolios of banks is growing, so now it is necessary not only to reduce the share of problem loans in the structure of the loan portfolio, but to prevent them from occurring in the future in order to ensure financial stability of a bank and build the population's confidence in the banking system. Consequently, the development of a strategy for minimizing bad loan debts of a bank is currently is given the highest priority in the activities of banking institutions, which makes this study topical.

A number of scientists have been trying to find solutions to problems caused by bad loan debts of a bank in Ukraine, namely V. L. Kloba [1], O.R. Yaremenko [2], whose research papers highlighted the issue of the essence and current state of banks' bad loan debts, A.V Oliynyk [3], who analyzed the impact of problem loans on solvency of banks in Ukraine, O.I. Baranovsky [4], T.M. Bolhar [5] devoted their research to methods of identifying problem loans and the improvement of banking institutions, V. Mishchenko, V. Krylov, M. Nikonova [6] studied the world experience and possibilities of in Ukraine restructuring of loans in terms of crisis, I. Y. Taranukha [7], P. M. Chub [8], whose scientific papers analyzed approaches to the definition of bad loan debts, I. Osadchy [9] devoted his works to developing ways to improve troubled assets management at Ukrainian banks. However, despite the achieved scientific results, many issues in this area remain unresolved, in particular, the development of a bank strategy for minimizing banks' bad loan debts.

The objective of the paper is to extend theoretical and methodological principles on the basis of a systematic approach, as well as to develop strategic directions of minimization of banks' bad loan debts.

The theoretical basis of the research is composed of the latest scientific views about the essence of the concept of "problem loan" and "adversely classified assets" and the specifics of their emergence. The research involved using the following methods and techniques: abstraction - to generalize scientific approaches to the definition of the essence of the concept of "problem loan"; methods of theoretical generalization and comparison - to clarify the conceptual apparatus when studying the reasons for the emergence of bank's bad loan debts; the method of analogy to substantiate the possibilities of introducing the improved classification of problem loans; grouping and factor analysis - to assess the volume of problem loans within Ukraine's banking system in general and at JSC Oshchadbank in particular, and maintenance of such loans at the safe level for the bank in terms of the total cost of loans; statistical and comparative analysis - to identify the state of overdue loans in the total amount of loans and its impact on the results of domestic bank activity. The research of scientific approaches to the specifics of problem loans in order to minimize banks' bad loan debts is based on the development of scientific publications of foreign and domestic authors and open sources of information. 


\section{MAIN MATERIAL}

The essence of problem loan as a kind of bank assets. It is known that managing a problem asset should be individual in nature, but it should be based on certain standard techniques, scenarios and schemes drawn up for each particular case. This requires a thorough understanding of the nature of problem loans, since there is no consensus among scientists on this issue. We will commence to clarify the essence of a problem loan as a variant of bank assets with an analysis of its individual components. Thus, business assets should be treated as the totality of tangible and intangible assets of the enterprise that have money value, as well as values in the form of depreciation, provision, goodwill, etc., the formation and use of which will bring future economic benefits [10]. The above definition fixes tangible and intangible assets, as well as their affiliation to the enterprise, the ability to generate income in the future.

"Problem" (from Greek - an obstacle, a task) in a broad sense is a comprehensive theoretical or practical issue that needs to be studied and solved. O. V. Kolesnikov [11] asserts that the problem is understood as a scientific problem of a complex nature which covers a significant area of research and has a prospective value. Moreover, before defining the essence of the notion of "problem loan", it is necessary to clarify the meaning of the term "adversely classified assets". According to the terminology dictionary, adversely classified assets are defined as part of bank assets that do not meet the criteria for standard debt. As we can see, the above statement is rather general and does not describe the essence of problem loans.

In their papers, researchers provide a variety of definitions of problem loans. There is currently some controversy regarding the composition of such loans. Thus, the International Monetary Fund defines them as nonperforming loans (NPL) [12]. In accordance with the current classification, the NBU refers doubtful and bad loans to nonperforming loans. Along with nonperforming loans, the NBU singles out the concept of "problem loans" that include overdue and doubtful loans. Problem loans should encompass the amount of arrears on scheduled payments of overdue loans in accordance with the financial statements, rather than the total amount of overdue loans [13].

The analysis of numerous sources of information gives grounds to conclude that the conceptual apparatus used by various authors there contains such synonyms for bad loan debts as "problem loan", "troubled assets". Due to the critical consideration of the existing points of view presented by scientists along with our own research allow us to formulate our own definition of this concept. A problem loan is a loan which is unlikely to be recovered from borrowers, that is, when there is jeopardous non-fulfilment of loan contract obligations to the bank; when one or several payments are not timely paid; when there is depreciation of collateral; when there are signs of deterioration of the borrower's financial condition or in case of negative information regarding his/her failure of fulfilling his/her obligations, and other circumstances that allow the bank to have doubts about the repayment of the loan.

Analysis of the status of bad debt for loans. As practice shows, large volumes of overdue loans lead to a decline in trust in the bank's trustworthiness for depositors, creditors and shareholders, the emergence of solvency and liquidity problems, and a deterioration in the bank standing. Noteworthy is the fact that during the period in question there was a significant deterioration in the financial stability of banking institutions and a number of banking institutions left the market. According to the NBU, as of January 1, 2016, there were 117 operating banks registered in Ukraine, and as of January 1, 2019 their number reduced to 77 operating banks. These data indicate deterioration in the banking sector and the loss of the above-mentioned confidence in banks. Table 1 shows the performance of commercial banks for the period from 01.01.2018 to 01.01.2019 (UAH million).

TABLE I. TOTAL ASSETS OF UKRAINIAN COMMERCIAL BANKS AS OF JANUARY 1, 2018 - JANUARY 1, 2019(UAH MLN.)

\begin{tabular}{|c|c|c|c|c|}
\hline Exponent & $\begin{array}{l}01.01 . \\
2018\end{array}$ & $\begin{array}{l}\text { 01.01. } \\
2019\end{array}$ & $\begin{array}{l}\text { Absolute } \\
\text { deviation }\end{array}$ & $\begin{array}{c}\text { Relative } \\
\text { deviation }\end{array}$ \\
\hline Assets (total) & 1320112 & 1360764 & 40652 & $3.1 \%$ \\
\hline $\begin{array}{l}\text { Assets in foreign } \\
\text { currency }\end{array}$ & 495393 & 494820 & -573 & $-0.1 \%$ \\
\hline $\begin{array}{lr}\text { Total assets } & \text { (not } \\
\text { adjusted } & \text { for } \\
\text { reserves) } & \\
\end{array}$ & 1891263 & 1911093 & 19830 & $1.0 \%$ \\
\hline $\begin{array}{l}\text { Total assets (not } \\
\text { adjusted) in } \\
\text { foreign currency }\end{array}$ & 795195 & 778722 & -16473 & $-2.1 \%$ \\
\hline $\begin{array}{l}\text { Correspondent } \\
\text { accounts opened } \\
\text { in other banks }\end{array}$ & 89282 & 86547 & -2735 & $-3.1 \%$ \\
\hline $\begin{array}{l}\text { Term deposits } \\
\text { with other banks } \\
\text { and loans to other } \\
\text { banks }\end{array}$ & 1988 & 1992 & 4 & $0.2 \%$ \\
\hline Securities & 422917 & 480608 & 57691 & $13.6 \%$ \\
\hline Granted loans & 1144904 & 1118618 & -26286 & $-2.3 \%$ \\
\hline $\begin{array}{l}\text { loans to public } \\
\text { authorities }\end{array}$ & 2508 & 2865 & 357 & $14.2 \%$ \\
\hline $\begin{array}{l}\text { loans to business } \\
\text { entities }\end{array}$ & 939037 & 919054 & -19983 & $-2.1 \%$ \\
\hline $\begin{array}{ll}\text { loans } & \text { to } \\
\text { individuals } & \\
\end{array}$ & 203321 & 196634 & -6687 & $-3.3 \%$ \\
\hline $\begin{array}{l}\text { loans to non-bank } \\
\text { financial } \\
\text { institutions }\end{array}$ & 38 & 66 & 28 & $73.7 \%$ \\
\hline
\end{tabular}

Practice proves that, according to the requirements for loan repayments, the bank bears additional costs, and part of the bank assets is blocked as non-productive. Each bank has problem loans in its portfolio, and therefore the main issue is to establish the level of such loans which would be acceptable for the bank regarding the total cost of loans granted. For foreign banks, the following values of indicators are considered acceptable: specific gravity of written off loans in total issued $-0.25-0.75 \%$; the share of overdue loans (over 90 days) in the total amount issued $-0.5-3 \%$. For the domestic banking system, the value of similar indicators varies in a wide range: from 2 to $60 \%$ [15].

The carried out analysis showed that the share of problem loans in the total amount of loans granted by Ukraine's banks as of December 1, 2016 amounted to $30.6 \%$. Some part of banks with Ukrainian capital was delaying the recognition of problem loans, and the appropriate formation of reserves. In 2017, banks were urged to reflect the true picture of the quality of debt capital due to a diagnostic survey of the banks and the entry into force of a new credit risk assessment 
procedure in accordance with the NBU Board's "Resolution on Determining the Size of Credit Risk by Bank of Ukraine for Active Banking Operations" dated June 30, 2016, No. 351 [16]. According to the research conducted by the NBU in July 2017, the share of problem loans in the portfolio of banks reached its historic maximum and amounted to $58 \%$.

Problem loans in the bank's portfolio can be divided into several categories, according to the seriousness of the problem. Each category has its own characteristics and indicators used by a bank. Thus, a bank should develop its complex of measures applied to each category of problem loans, well-tested algorithms of interaction between units in the event that certain signals arrive, thought-out behavioral patterns for various degrees of effectiveness of the measures taken. According to N. Lykova [17], all the categorized categories are reasonably grouped into two blocks: loans in the stage of early warning and loans with identified signs of problem. From our point of view, this classification is not complete; therefore we propose to allocate a few more blocks, namely: loans at the stage of enhanced control and loans with existing signs of problem. We believe that our adjusted approach is justified because it strengthens the objectivity of the classification provided and lays out the specifics and the scope of problem loans.

Despite the active efforts put by banks to develop methods and models for minimizing losses caused by problem loans, managing bank's problem assets one remains of the acute issues. Besides, special attention should be paid to the debts of state banks since they are system-forming and account for about a third of the total assets and are the source of significant systemic risks for the financial sector. That is why we consider it necessary to analyze the volume of problem loans in Ukraine's banking system in general and JSC Oshchadbank in particular. Figure 1 presents data on the volume of loans granted to individuals and business entities from 2013 to 2018 .

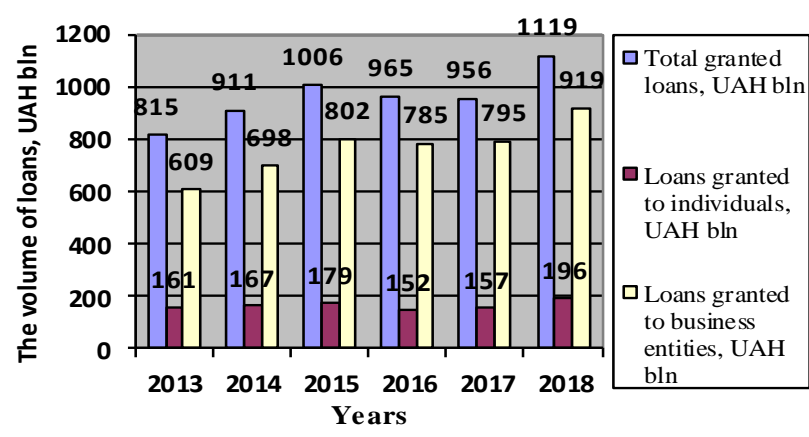

Fig. 1. Fig.1 The volume of loans granted to individuals and business entities from 2013 to 2018

\section{Source: built up on the materials [13]}

The analysis showed that by 2015 the total volume of loans granted by banks, as well as those provided to individuals and business entities, had been increasing; however, with the slowdown in the economic growth along with unfavorable foreign economic conditions, the total volume of granted loans began to decrease and, as of January 1, 2017, the total share of loans provided declined to UAH
956 billion. However, in 2018, the total volume of loans granted increased to UAH 1119 billion, loans to the population continued to grow dynamically and amounted to UAH 196 billion, and, despite the significant increase in loans to individuals, loans to economic entities amounted to 919 billion UAH. [13].

Figure 2 shows the volume of loans to legal entities and individuals granted at JSC Oshchadbank.

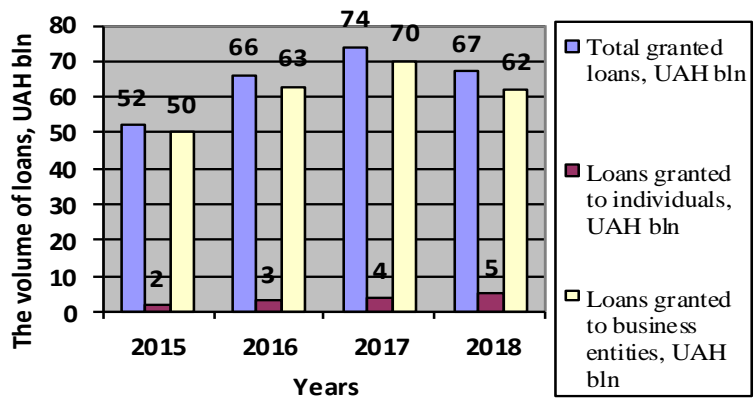

Fig. 2 Volume of loans to legal entities and individuals granted at JSC Oshchadbank

Source: built up on the materials [13]

The analysis showed that the total loan portfolio of JSC Oshchadbank in 2018 amounted to 67 billion UAH, including loans to individuals (UAH 5 billion), and loans to legal entities (62 billion UAH). Compared to 2017, the individuals' loan portfolio increased by $25 \%$, while the corporate loan portfolio decreased by $12 \%$, which was due to changes in the bank's credit policy and the transfer of the institution to new lending rules.

The introduction of the Resolution No. 351 "Regulations on Determining the size of credit risk of active banking operations by Ukraine's banks" [16] and the transition of the banking system to the international practice of defining nonperforming exposures / loans (NPE / NPL) made it possible to assess the real level of non-performing loans in Ukraine. Their share turned out to be the largest one in global practice throughout the history of observations. The NBU has been regularly publishing statistics on provided loans from the point of view of debtors and banks since September 2017. In total, according to the regulator's methodology, there are 10 classes of business borrowers and 5 classes of individual borrowers. The National Bank For loans includes loans to legal entities with more than 91 days past due and a $100 \%$ probability of default in class 10 . Similar loans to individuals refer to class 5 . The largest concentration of loans in class 10 comes from the four state banks: PrivatBank, Oshchadbank, Ukreximbank and Ukrgasbank. In total, they have over UAH 337 billion "bad" loans. Over the period from 2014 to 2017, the share of overdue debts increased by 50.3 r.p. During the last months of 2017, the share of non-performing loans decreased by 2.2 r.p. mainly due to the gradual development of new lending. In January 2018, the share of nonperforming loans increased by 2 r.p. due to the statistical effect of changes in the chart of accounts: a part of accrued but not paid interest incomes was transferred to the reserves accounts. However, by the end of June 2018, the share of 
non-performing loans had decreased and made $55.06 \%$. According to the National Bank of Ukraine, at JSC Oshchadbank in particular, this indicator decreased from $59.1 \%$ to $56.3 \%$; at other banks with a state share - from $59.11 \%$ to $59.09 \%$; in banks of foreign banking groups from $42.54 \%$ to $41.75 \%$, and at banks with private capital they increased from $24.09 \%$ to $24.6 \%$. In June, the volume of non-performing loans in JSC Oshchadbank increased by 2,092 billion UAH - up to 55,231 billion UAH. The increase in consumer lending allowed improving the quality of retail loans portfolio, and the sale of bank's non-performing foreign currency business loans - the quality of corporate loans portfolio. A comparative analysis of the share of NPL with other countries that had significant NPL shares proved that Ukraine ranks first in this "rating" [18].

While the analysis was being conducted, the NBU's actions were to raise the discount rate from $6.5 \%$ in 2013 to 14.0\% in 2014. Until March 4, 2015 the discount rate was $19.5 \%$, but then it increased by 10.5 r.p. and accounted for $30.0 \%$ - the historical maximum level for the banking system of Ukraine. Rapid growth of the discount rate caused a rise in the cost of credit for banks, which in turn raised interest rates on their loans. The growth of the discount rate equally deteriorated economic conditions for financial institutions, the manufacturing sector and the population of the country. The high discount rate caused a decrease in demand for loans, indicated high inflation in the country and led to uncertain expectations on the market. In the following years, the regulator began to gradually decrease the discount rate from $27 \%$ as of August 28, 2015 to $14 \%$ as of October 28,2016 . As a result of revision of the discount rate as of April 14, 2017 it was reduced to 13\%, as of May 26, 2017 to $12.5 \%$, and as of December 15, 2017 it was raised to $14.5 \%$. However, such a decrease in the discount rate had almost no effect on the intensification of lending to the real sector of economy. On January 24, 2018, the discount rate was raised again to $16 \%$, however, during September 7, 2018 - April 25, 2019, the discount rate made 18\%, which indicates a revision of lending rates and a harsher customer selection policy [15]. Since April 26, 2019 the discount rate has been reduced by $0.5 \%$ and now makes $17.5 \%$.

The estimation of the share of problem loans by branches of economy, serviced by JSC Oshchadbank, proved that in order to overcome the negative effects of the increase of adversely classified loans, the bank uses traditional instruments of risk reduction - that is, collateral provided by movable and immovable property and provision of reserves for credit operations, while the main focus should be on the oil and gas industry. The development of ways of minimizing bad loan debts. The most noticeable progress in granting loans to individuals in the national currency was due to putting new lending on a wide scale. Banks should accelerate the clearance of balances by selling and writing off non-performing loans. If the NBU forecast is implemented, the quality of banks' loan portfolios will increase. But, according to the NBU calculations, the return of bad loans will not become massive, even if the economic conditions improve considerably.

At the same time, the quality of foreign currency loans to individuals and hryvnia loans to business will hardly change. If the economy is slowly recovering, while the hryvnia exchange rate is decreasing, the existing problem loans portfolio will hardly recover, remaining a source of systemic risks.

According to the calculations of the NBU, the share of non-performing currency loans to individuals will grow and approach the $100 \%$ indicator. At the same time, the quality of hryvnia loans will grow. The quality of auto loans and other loans will be restored to the pre-crisis indicators [19].

In 2017, banks began to work more actively with bad loan debts writing-off or selling them at a discount. There has been a restructuring of debts of many business groups that are already able to service the debt, albeit at lower rates than before the crisis. However, the imperfection of the judicial system makes it impossible or very time-consuming to recoup the losses from problem loans by seizing collateral. Indeed, today, restructuring, sale and write-off remain the main instruments for clearing banks' balances from toxic loans. In November 2017, with the support of the EBRD the NBU has drafted a bill "On Debt Management" [20], according to which banks will be able to sell problem debts to specialized debt management companies that must meet stringent requirements to the size of share capital and funding sources and will be limited in possibility to attract funds of individuals. Such companies will negotiate directly with debtors to resolve issues and conditions for debt repayment. Adoption of the law will allow banks to quickly clear the balance of problem loans and improve their financial position. The NBU will periodically update the model and its own default probabilities estimation to take into account changes in economic conditions. The first update took place during the first half of 2018. In addition, the NBU has been introducing an annual stress test to assess banks' resilience to economic shocks since 2018. In 2018, almost all key indicators of the banking sector performance were positive: the refined banking sector received a record profit for more than a decade, the average return on capital exceeded $14 \%$ with retail lending continuing to grow at a high rate throughout the year. Corporate lending also increased, especially in the segment of high-quality borrowers.

At the same time, banks have already demonstrated almost all their losses from the deterioration of the quality of their loan portfolios, although significant volumes of nonperforming loans still remain on balance sheets. Another important indicator - the coverage of NPL by reserves made $90 \%$, and this level is acceptable since it complies with international standards [21]

The success of a bank in reducing the proportion of problematic loans in its loan portfolio largely depends on that, as far as large attention is spared by a bank to quality of loan yet to her delivery and during all process of crediting, ie how effective preventive (precautionary) measures are designed to prevent the occurrence of origin of problem loan. We believe that when a loan is considered problematic, the bank can manage such loans in two main ways:

1) Formation of a strategy for minimizing loan indebtedness using various methods, ways and instruments aimed at the recovery of the most problematic loan debt, or alternatives to its recovery, which, unlike the existing ones, will promote the increasing of the efficiency of managerial decision-making, as reflected in Figure 3. 


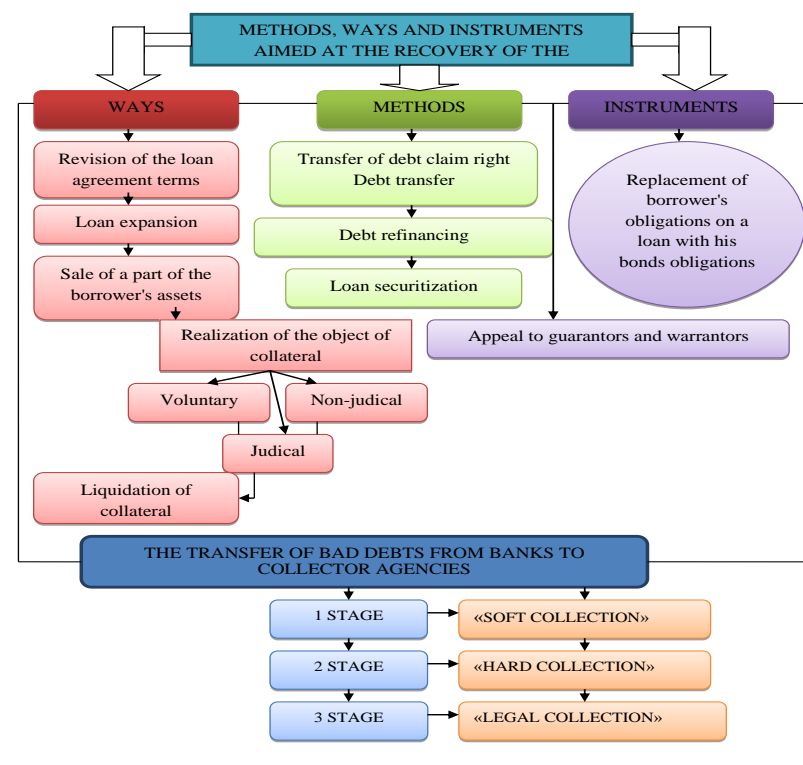

Fig.3. A strategy of minimizing bad loan debts

2) Basing on the fact that one of the directions is the improvement of the work with mortgaged property, we consider it important to introduce the LVPC coverage ratio for potential bank claims, which takes into account the liquidation value of the collateral object instead of the LTV coverage ratio which is based on the market value of the collateral. This suggestion is explained by the fact that the market value takes into account a rather long period of exposure, and in most cases selling property is protracted, and banking institutions are unable to wait long for collateral to be realized. The foregoing is a basic condition of maintaining a favorable credit potential and efficient functioning of the bank.

\section{CONCLUSIONS}

The analysis of different approaches to the definition of a problem loan, allowed us to suggest the definition of this concept which is treated as a loan which is unlikely to be recovered from borrowers, that is, when there is jeopardous non-fulfilment of loan contract obligations to the bank; when one or several payments are not timely paid; when there is depreciation of collateral; when there are signs of deterioration of the borrower's financial condition or in case of negative information regarding his/her failure of fulfilling his/her obligations, and other circumstances that allow the bank to have doubts about the repayment of the loan. The analysis of the volume of problem loans in the banking system of Ukraine in general and in JSC Oshchadbank in particular showed that in Ukraine, along with the signs of a negative economic growth and unfavorable foreign economic situation, the total volume of provided loans began to decline, but the share of overdue loan debts increased due to objective macroeconomic reasons and low level of management in assessing the borrower's solvency. It is recommended to further improve the banks' management of bad loan debts by taking into account the proposed strategy in order to minimize problem loans using various methods, ways and instruments aimed at the recovery of the most problematic loan debt, or alternatives to its repayment; the usage of the LVPC coverage ratio for potential bank claims in the process of assessing the level of credit contracts throughout the entire lending period. The development of directions for minimizing the problematic debt in the long run will allow banks to maintain their credit potential, an also will ensure the completeness, timeliness and effectiveness of management measures.

\section{REFERENCES}

[1] V.L. Kloba "Bank Situation Center as an Effective Direction for Improving Debt Management", Scientific Bulletin of NLTU Ukraine, no. 19.8, pp. 240-246, 2009.

[2] O.R. Yaremenko "Problem loans to banks: essence, current state and methods of their regulation", Global and national problems of economy, issue 8, pp. 1080-1085, 2015.

[3] A.V. Oliinyk, and I.V.Volovnyk "Bad loans and their impact on the solvency of banks in Ukraine", Economics and society, issue 6, pp. 300-307, 2016.

[4] O.Baranovskyi ““'Problem banks: detection and treatment", Bulletin of the National Bank of Ukraine, no. 11, pp. 18-31, 2009.

[5] T.Bolhar " Features of State and Intra-Bank Regulation of Problem Loans in Ukraine ", Bulletin of the National Bank of Ukraine, no. 12, pp. 23-29, 2014

[6] V.Mishchenko, V.Krylova, and M.Nikonova, "Credit Restructuring in Crisis: World Experience and Possibilities of Application in Ukraine ", // Bulletin of the National Bank of Ukraine, no. 5, pp. 12-17,2009.

[7] I.Yu.Taranukha " Approaches to determining bad credit debt ". URL: http://dspace.uabs.edu.ua/bitstream/123456789/6911/1/Taranukha.PD F.5. Accessed on: June 19, 2019

[8] P.M. Chub , and S.I. Khodakevych " Problematic Credit Debt of Banks in Ukraine and the World ", Investments: Practice and Experience, no. 18, pp. 41-46, 2016.

[9] I. Osadchyi “ Ways to Improve Working with Problem Assets of Ukrainian Banks ", Bulletin of the National Bank of Ukraine's Banking University, no. 11, pp. 11-16, 2011.

[10] V.V. Skorobohatova. "The essence of the category "Assets": Analysis of scientific sources", Problems of theory and methodology of accounting, control and analysis, no. 3 (21), part 2, pp.338-348, 2011.

[11] O.V. Kolesnikov, Basics of the scientific research, Kiev, Ukraine: Center for Educational Literature, 2011.

[12] Regional economic outlook. URL: http://www.imf.org/external/pubs/ft/reo/2011/eur/eng/ereo0511.htm. Accessed on: June 19, 2019.

[13] Official site of the National Bank of Ukraine. URL: [http://www.bank.gov.ua. Accessed on: May 09, 2018.

[14] Financial portal of the Ministry of Finance URL: http://index.minfin.com.ua/bank/stat/count.php. Accessed on: June 19, 2019.

[15] Performance of Ukrainian banks. URL: https://bank.gov.ua/control/ uk/publish/article?art id=28905601. Accessed on: April 15, 2019.

[16] Regulation on determining the size of credit risk on active banking transactions by Ukrainian banks URL: http://zakon0.rada.gov.ua/laws/show/v0351500-16. Accessed on: June 19, 2019

[17] N. M. Lykova. "Approaches to the classification of bad loans and methods of managing them in a commercial bank ", Banking. no. 11, pp.18-25, 2012.

[18] National Bank of Ukraine Financial Stability Report from 04.12.2017r. URL: https://bank.gov.ua/doccatalog/document?id=60764561. Accessed on: June $15,2019$.

[19] Banking analytics: analysis of Ukrainian banks: overview, graphs, facts. URL: http://bankografo.com/analizbankiv/bankivska-analityka. Accessed on: September 25, 2018.

[20] Draft Law on Peculiarities of Overdue Debt Management. URL: http://w1.c1.rada.gov.ua/pls/zweb2/webproc4 1?pf3511=61710. Accessed on: May 25, 2019.

[21] National Bank of Ukraine Annual Report 2018: URL: https://bank.gov.ua/doccatalog/document?id=95170958. Accessed on: May 25, 2019. 